\title{
The Double Role of Hindu Women in Bandar Lampung
}

\author{
Wayan Sukarlinawati \\ Universitas Hindu Indonesia, Denpasar, Indonesia \\ Corresponding author email: karlinawayan@gmail.com
}

\author{
I Ketut Suda \\ Universitas Hindu Indonesia, Denpasar, Indonesia \\ Email:suda@unhi.ac.id \\ I Wayan Budi Utama \\ Universitas Hindu Indonesia, Denpasar, Indonesia \\ Email: budiutama904@gmail.com
}

\begin{abstract}
This study focuses on (1) the dual roles of Hindu women in Bandar Lampung, (2) the forms of the dual roles of Hindu women in Bandar Lampung, (3) the implications of the dual roles of Hindu women in Bandar Lampung for themselves, their families, and society. The theories used in this study include the first theory of Abraham Harold Maslow's motivation which emphasizes the hierarchy of needs and motivations, the second theory of Liberal Feminism in dismantling the concept of patriarchy, and the third, the theory of Hegemony to dissect the problems regarding the implications of Hindu women for themselves, their families, and implications for society in Bandar Lampung. This study uses a phenomenological approach with a critical emancipatory knowledge paradigm. The method used is observation, interviews, and literature study with data analysis techniques with qualitative interpretation to explain the sociological phenomena observed in the field by the meaning given by the research subjects. The results of this study indicate that (1) The reasons why Hindu women have a dual role are due to economic reasons, social reasons, cultural reasons, reasons for patriarchal domination, and religious reasons, (2) The forms of dual roles of Hindu women include: as housewives, as women careers, as Hindu women, and as members of society, (3) The dual roles performed by Hindu women have implications for themselves, their families and society.
\end{abstract}

Keywords---dual roles, families, Hindu women, motivation, society

\section{Introduction}

The dynamics of culture in society often shift the position and role of women. The patriarchal culture in Balinese culture originates from the concepts of purusha and predana, which symbolize the eternal soul (spirit) (purusha), and the human body which has a changeable nature (prakirti). In society, this concept is better known as matters relating to men or purusha, and matters relating to women or predana. Dual roles are a phenomenon in the world of work that we often encounter, not a few women who participate in the industrial world. The role of women in the public sector is influential in their household, women are burdened with a double task, namely having to be responsible for their work in the public sector and the domestic sector (Rocheleau \& Edmunds, 1997; Rao, 1999; Abdullah, 1997).

The role of women as housewives is very decisive because they have to maintain, maintain and carry out their roles, both as regulators and housekeepers. But along with the development and dynamics of the times, there is a shift. The role of the wife in the family and society has changed, if in the past the wife was only responsible for the domestic, then the development was then not a few wives who worked outside the home because the husband's income was considered inadequate in meeting the needs of the family (Portman \& Gass, 2014; Patel et al., 1999). 


\section{Research Methods}

This study was designed using a qualitative approach with a critical emancipatory knowledge paradigm (critical emancipatory knowledge paradigm) to analyze social reality by questioning the inequality of existing social relations and explaining in-depth related to the dual role of Hindu women in Bandar Lampung (Saroha et al., 2008; Knott, 1996). This research was conducted in Bandar Lampung, this location was chosen intentionally for several reasons; (1) some conditions are difficult for Hindu women to experience in Bandar Lampung, resulting in quarrels and ending in divorce, (2) Based on data from the district court during 2019-2020 there were around 17,000 divorce cases, the trigger for the cause of the divorce was due to family economic problems and the presence of a third person, both from the side of women and men, (3) During the last five years there has been violence against women with details in 2017 and 2018 amounting to 922 cases, in 2019 there were 168 cases, in 2020 there were 300 cases, and in 2021 totaled 177 cases. The highest violence in cases of domestic violence (KDRT) is as many as $61.30 \%$ of cases, (4) The population is heterogeneous, (5) It is the capital city of Lampung province.

The type of data used in this study is qualitative data based on the problems studied by the researcher, namely about the dual role of Hindu women in Bandar Lampung. The primary data sources in this study are people called informants, they are appointed purposively which is a technique for determining informants with certain considerations. While the secondary data sources are in the form of documents, such as literature books, journals, magazines, and other reference sources related to this research (Drescher \& Schultheiss, 2016; Semaan et al., 2019).

Data collection techniques carried out in this study were carried out in 3 (three) ways, namely observation techniques, interviews, and document studies. The observation technique is carried out through observations based on empirical data and facts from informants. The interview technique was carried out to collect data through conversation and face-to-face with people who could provide information related to this research. Document studies are carried out by reviewing several documents or records that have occurred related to this research. The total number of Hindus in Bandar Lampung is 1,868 people. The traditional banjars that were formed are traditional village systems that become inseparable units and live side by side and help each other with the local population. Likewise, the existence of Hindu women in Bandar Lampung is involved and plays an active role in every activity in the Banjars as well as social activities carried out in the community.

\section{Research model}

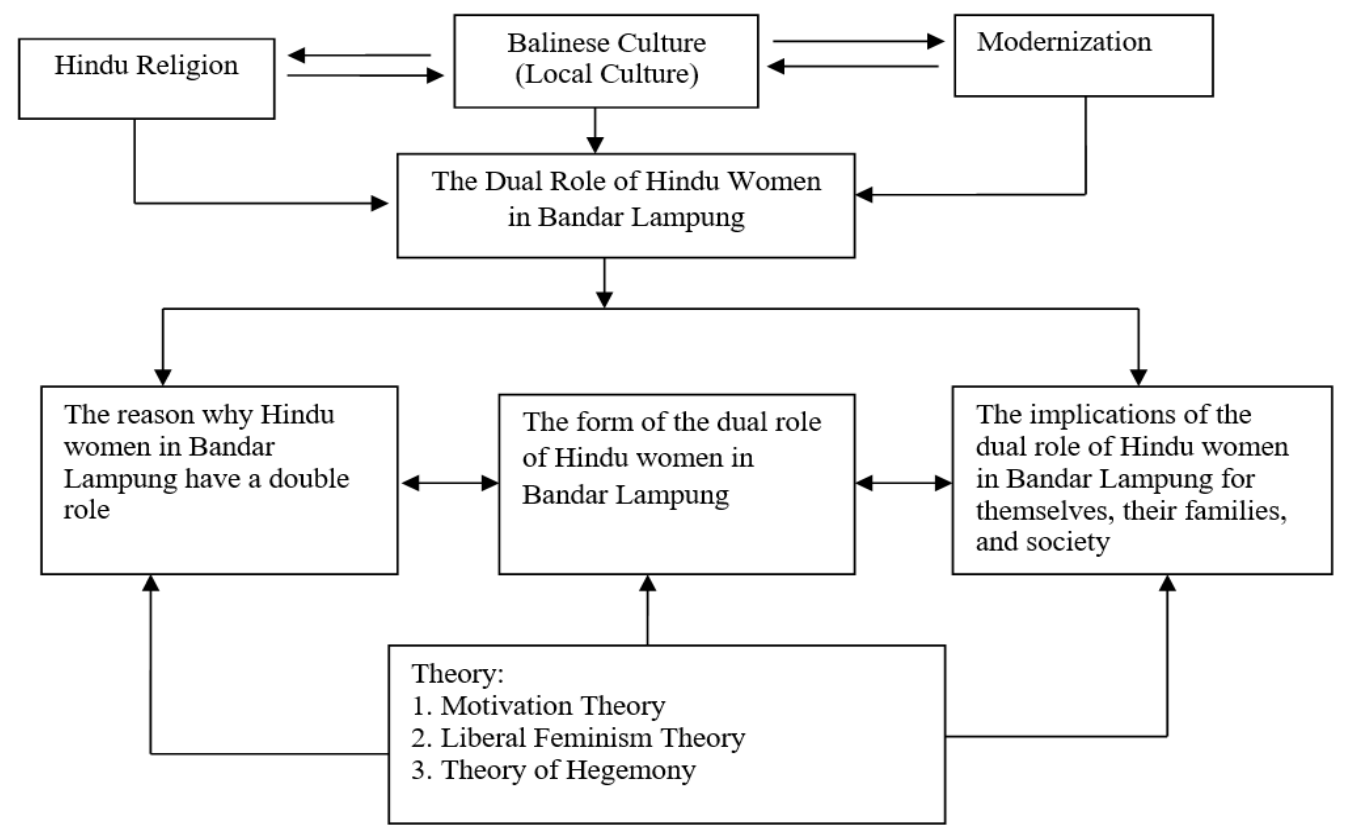

Figure 1. The dual role research model of Hindu women in Bandar Lampung

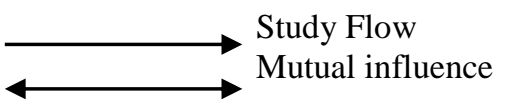




\section{Discussion}

Reasons for Hindu women in Bandar Lampung to play dual roles

- Economic reasons

Along with the development of an increasingly advanced society and accompanied by the fulfillment of increasing economic needs, forcing a woman as a wife in the family to participate in helping to fulfill the family economy, even though the main role of a wife is as a housewife. The involvement of women in the world of work is influenced by economic factors. The influence of a modern lifestyle that cannot be avoided by every individual, including women, tries to be able to fulfill their life needs, both primary and secondary needs. In overcoming this, women have the awareness to enter the public sector in fulfilling the family economy. With rising food prices, it is difficult for women to manage family finances, while husbands who are responsible for earning a living have insufficient income to meet family needs. This can be strengthened by the decision of the Governor of Lampung number G/526/V.08/HK/2020 regarding the determination of the City Minimum Wage (UMK) in Bandar Lampung in 2021, which is Rp. 2,739,983.04, - per month. If the income of a man as the head of the family in Bandar Lampung with an income of the UMK, it is certainly not sufficient to meet the needs of today's families. The demands for various necessities of life such as education, health, and the desire to own electronic goods cannot be ignored, as well as the influence of a modern lifestyle that cannot be avoided by every individual, including women. This is what encourages women to increase their productive role by filling the opportunities and opportunities that exist in the public sphere to meet their primary and secondary needs (Handayani et al., 2008; Wildan, 2009).

- Social Reason

The social role is the role played by women intending to be able to actualize themselves in society because women are directly involved in activities carried out in society. Hindu women face and play roles in the domestic, public, and social spheres (krama adat). Since 1978 has provided opportunities for women to participate in development. The involvement of women in various aspects of social life will have the consequence that women are one of the elements that are incorporated in one unit and show their interdependence with other elements. The reason or social factor that drives women in general activities is the desire to participate in an active environment.

- Cultural reasons

The role of religious customs is the role of women who are part of a socio-cultural community, women also instill cultural preservation in the implementation of traditional religious activities, by working on the needs of banten (religious ceremonial facilities) from the beginning of the process of planning, directing, coordinating, and controlling the implementation of the ceremony. religious customs until the activity is completed. All of these activities are carried out by Hindu women as a tradition that is passed on from generation to generation so that they can make Balinese culture stable or sustainable.

\section{Reasons for patriarchal domination}

The limitation of women's roles by patriarchal culture makes women become shackled and receive discriminatory treatment. This inequality between the roles of men and women is one of the structural barriers that causes individuals in society to not have equal access. In the customary law system, the position of Hindu women is indeed subordinated to men. This is strongly influenced by the family system prevailing in society which places women in a weaker position than men.

The family system of the Hindu community in Bandar Lampung adheres to the Purusha or male family system. Descendants are passed on through men, so the value of daughters in the family is not as important as that of men. From the construction of these cultural customs, it was then determined that the son was decided as the heir in the family while the daughter unless designated as sentana rajeg (daughter who was confirmed as the successor of the offspring like a son) did not have the status of an heir. This of course triggers a gap in social life in society, because women have always been a figure dominated by men. This situation is very contradictory and contrary to the spirit of gender equality which wants togetherness and equality in its implementation between men and women (Arjani, 2006; Wibowo, 2012; Thompson, 1985). 


\section{Religious reason}

The role of women as organizers of religious activities in Hindu families is very clear because most of them are carried out by women or mothers. Besides being active in earning a living outside the home, Hindu women also play an active role in the household such as taking care of the house, children, and husbands. Besides that, a woman also plays an active role in taking care of worship and preparing all the equipment. Swadharma of women as organizers of religious activities is very dominant, namely from making, offering with prayers or mantras, to invoking the safety of themselves and their families and ancestors in their families (Aini, 2016; Alwasilah, 2008; Mazumdar \& Mazumdar, 1999).

\section{Forms of the dual role of Hindu women in Bandar Lampung}

- As a Housewife

The career of a woman/housewife requires time management or good time sharing so that household affairs can be completed before leaving for work. This means that good cooperation between husband and wife is needed in terms of division of tasks, especially for families who do not have household assistants. This can be overcome as long as it is based on good communication between men who act as husbands and women who act as wives. Carrying out two roles at once in the household and career for a woman is not easy. The task of women in the domestic sector and the public sector is a dual role that is carried out simultaneously, and in carrying out these two roles women are required to be balanced in carrying out both roles. Married women have an important role in improving family welfare.

- As a Career Woman

Even though women with multiple roles are already very busy with their work in the public sector, they are still responsible for housework in the domestic sector. The dual role of modern women with all their activities must be able to divide their time for career and family. These roles are, among others, career women, child educators, household managers, socialization roles, and roles as community members. Many factors encourage women to turn into career women, for example, a woman will enter the world of work because it is driven by education factors because education can give birth to women who are experts in various fields, who are capable of pursuing a career. Factors forced conditions and needs, factors of economic independence, so as not to depend on husbands, motives for seeking wealth, motives to fill spare time or pleasure, and motivation to develop talents.

- As a Hindu Woman

The view in Hinduism that glorifies women is very contradictory to the traditions and customary law in Bandar Lampung, this is because the people still adopt Balinese traditional traditions. Because in Balinese tradition and customary law it has not reflected gender equality. Because of the impact of patriarchal culture, the position of women is under men. As a result of the enactment of patriarchal culture in society, it tends to be one of the factors causing unfavorable treatment for women, especially in households such as discriminatory treatment.

- As a Community Member

The women in Bandar Lampung in carrying out their traditional cultural traditions in society adhere to the concept of Balinese Hindu tradition. Hindu women in Bandar Lampung not only play a role in taking care of the household, but also play a role in social activities, such as banjars, villages, and other social organizations. How big is the role of Hindu women in society, because it cannot be denied the importance of education, teaching, and science for Hindu women to bring progress to society, nation and state. Like men, women cannot be separated from social life (Ahmadi, 2003; Ahmadi, 1982; Suacana, 2016). During this development period, the role of women is sought to increase knowledge or skills according to their needs. Balinese Hindu women in Bandar Lampung participate in social life, especially in the banjar environment as customary manners. One of the customs that is maintained and implemented in Bandar Lampung is the application of the traditional banjar or banjar joys and sorrows. Through the banjar in the ngayah tradition, it can form an attitude of cooperation between traditional manners so that it can unite people with different religious, cultural, and traditional backgrounds. In addition, it also builds togetherness and strengthens unity between Hindus, especially Hindus in Bandar Lampung. 
Implications of the dual role of Hindu women on herself, family, and society

- Implications for women

The gap between men and women in the family and society causes the dual role of women to have an impact on him. The role played by women such as taking care of the family and working to help the family economy, it is clear that women's tasks are so heavy in the domestic sphere. But there is no respect for work in the reproductive realm by men because they consider reproductive work to be an obligatory job for women. The solution to the excessive workload experienced by women is a cooperation between family members in completing household work, namely through several strategies such as; increasing the level of education of women, rational discussions with men, parents, siblings, or other relatives in the family, discussions related to patterns in child-rearing, division of work in the household, to open up opportunities for women to have careers outside the home freely and comfortable (Abdullah, 1997; Agger, 2006; Menaka, 2017).

- Implications for Family

Women are the holders of important roles in the family, both as wives to their husbands and as mothers to their children. A woman with multiple roles has a consequence that is very tied to the family. The division of roles of women who work often creates an imbalance that causes multiple roles that collide with each other. Sometimes they even become stuck in managing their roles. This is because it is difficult to balance their role in the family (household) and the role in a job. Men generally assume that all domestic work is the responsibility of women.

- Implications for Society

The involvement of women in the community, especially in the existing banjars, is very necessary, especially when there is a piodalan event at the temple where women are involved in the implementation of the event. Because women are considered capable of identifying community needs that men do not think about, such as preparing consumption needs, preparing needs in terms of offerings (banten/upakara). The position of Hindu women in Bandar Lampung is more dominant in every activity held in the community, in this case, the banjar. Article 31 of Law Number 1 of 1974 concerning Marriage, namely the position of the wife is in balance with the rights and position of the husband in domestic life and social life together in society.

\section{Research finding}

Based on the results of data analysis that has been carried out, several research findings can be stated, both factual and theoretical findings. The findings of this study are as follows:

\section{Factual finding}

- Women decide to work outside the home due to insufficient family economic conditions so they are motivated to work, this is supported by high levels of education and skills that affect their availability to enter the world of work, and good work productivity is driven by the emergence of support from the environment and women's desire to continue their careers.

- Marginalization and restrictions in decision-making that occur to women because they are reinforced by customs and religious interpretations, Balinese culture with a strong patrilineal kinship system is one indicator of the cause of the gender gap experienced by Hindu women, especially in Bandar Lampung, especially against women from other ethnicities who recently converted to Hinduism by marriage.

- The role of women in the social sphere (banjar) has a more dominant role than men because in this case women have the same ability as men in terms of interacting in society even though the activities they do are still on a small scale, but It can be seen that women have a significant share in the social sphere of society.

\section{Theoretical finding}

- The theory of motivation proposed by Abraham Harold Maslow (1964:8), explains that humans are motivated to fulfill their life needs. This condition shows that the theory of motivation is in line with the reality faced by Hindu women in Bandar Lampung, they are motivated by themselves to participate in helping meet the economic needs of the family.

- The liberal feminism theory used in this study is in line with the role of career women in Bandar Lampung. Hindu women fight for freedom and equal rights, against sexual discrimination in the political, social, 
economic, and personal fields. The motivation that drives women to work proves that a woman who is described as a weak, emotional, sensitive, and unreasonable person who is considered fit to be in the domestic sphere is not true.

- The dual role played by Hindu women in Bandar Lampung, namely the domestic role (as housewives), the public role (as workers), and social roles (as traditional manners) at the same time, is in line with the concept of three roles or the theory of the triple role proposed by Moser. Moser stated that work in the productive and reproductive spheres is more dominated by women.

- Hegemony theory views the culture that occurs in society and patriarchal culture related to the social structure in society, men have superiority and even have the right to dominate women in various ways, there is even an assumption that women's position in customs is considered weak, so that in traditional deliberations women not included. This can be broken because it is not in line with the reality of Hindu women in Bandar Lampung. Hindu women can participate in social or community activities, women in the social sphere (banjar) have a more dominant role than men. This has been regulated in Article 31 of Law Number 1 of 1974 concerning Marriage, namely the position of the wife is balanced with the rights and position of the husband in domestic life and social life together in society.

\section{Conclusion}

Based on the results of research that has been done, several conclusions can be drawn, namely:

- Reasons for Hindu women in Bandar Lampung to carry out dual roles: (1) Economic reasons, because the needs of the family cannot be fulfilled by men as husbands, so they demand women as wives to work in looking for a living to meet the needs of their families, (2) Social Roles proves that the involvement of women in social roles can be a place for a wife to release their boredom in the family so that it has a positive impact on women, (3) The dominance of the Balinese cultural patriarchy provides a strong impetus for Hindu women in Bandar Lampung to work hard, (4) The role of women as organizers of religious activities is very important because most of them are carried out by women.

- The forms of dual roles performed by Hindu women in Bandar Lampung are: (1) As housewives, there is a lack of understanding of the contents of the Hindu religious scriptures related to gender equality so that the subordination of women still occurs both in the family and in the community. society, (2) The career of Hindu women who leave the domestic space to the public sphere requires support and motivation from those closest to them, especially husbands so that family life continues to run well and harmoniously, (3) Hindu women have a very important role in every aspect of life. religious ceremonies, but this role is not in line with the rights given to women, especially women who have just entered Hinduism, (4) The role of Hindu women in Bandar Lampung in carrying out their cultural traditions in society adheres to the concept of Balinese Hindu tradition.

- The dual role of Hindu women in Bandar Lampung has implications for several things, namely: (1) Implications for her, the ability to manage time and the household is one of the most frequent difficulties experienced by women who work in the public sector, (2) Implications for women working in the public sector. family, the role of women with dual roles even though they are very busy with their work in the public sector they are still responsible for family and homework, (3) the implications for society, the social system of Hindu society is based on the spirit of menyama braya, namely the value of life that considers all members of society are brothers.

\section{References}

Abdullah, I. (1997). Dari Domestik ke Publik: Jalan Panjang Pencarian Identitas Perempuan. dalam Sangkan Paran Gender, Yogyakarta: Pustaka Pelajar.

Abdullah, I. (1997). Sangkan paran gender. Pustaka pelajar.

Agger, B. (2006). Teori Sosial Kritis: Kritik. Penerapan dan Implikasinya, Yogyakarta: Kreasi Wacana, cet ketiga.

Ahmadi, H. A. (1982). Sosiologi pendidikan: membahas gejala pendidikan dalam konteks struktur sosial masyarakat. Bina Ilmu.

Ahmadi, H. A. (2003). Ilmu Sosial (Dasar Mata Kuliah Dasar Umum).

Aini, D. (2016). Strategi penyeimbangan peran ganda perempuan (studi kasus pada proses pengambilan keputusan perempuan bekerja di Dusun Kaplingan, Kecamatan Jebres, Kota Surakarta). SOSIALITAS; Jurnal Ilmiah Pend. Sos Ant, 5(2). 
Alwasilah, A. C. (2008). Filsafat bahasa dan pendidikan. Diterbitkan atas kerjasama Sekolah Pasca Sarjana Universitas Pendidikan Indonesia dengan Remaja Rosdakarya.

Arjani, N. L. (2006). Peran gender dalam kehidupan masyarakat adat di Bali. Kembang Rampai Perempuan Bali, 122.

Drescher, A., \& Schultheiss, O. C. (2016). Meta-analytic evidence for higher implicit affiliation and intimacy motivation scores in women, compared to men. Journal of Research in Personality, 64, 1-10. https://doi.org/10.1016/j.jrp.2016.06.019

Handayani, T., Sugiarti, \& Dharma, S. (2008). Konsep dan teknik: penelitian gender. Universitas Muhammadiyah Malang (UMM) Press.

Knott, K. (1996). Hindu Women, Destiny andStridharma. Religion, 26(1), 15-35. https://doi.org/10.1006/reli.1996.0002

Mazumdar, S., \& Mazumdar, S. (1999). 'Women's significant spaces': Religion, space, and community. Journal of environmental psychology, 19(2), 159-170. https://doi.org/10.1006/jevp.1999.0117

Menaka, G. (2017). Women empowerment in India. International Journal of Linguistics, Literature and Culture, 3(4), 1-6. Retrieved from https://sloap.org/journals/index.php/ijllc/article/view/212

Patel, V., Araya, R., De Lima, M., Ludermir, A., \& Todd, C. (1999). Women, poverty and common mental disorders in four restructuring societies. Social science \& medicine, 49(11), 1461-1471. https://doi.org/10.1016/S02779536(99)00208-7

Portman, D. J., \& Gass, M. L. (2014). Genitourinary syndrome of menopause: new terminology for vulvovaginal atrophy from the International Society for the Study of Women's Sexual Health and the North American Menopause Society. Maturitas, 79(3), 349-354. https://doi.org/10.1016/j.maturitas.2014.07.013

Rao, S. (1999, May). Woman-as-symbol: The intersections of identity politics, gender, and Indian nationalism. In Women's studies international forum (Vol. 22, No. 3, pp. 317-328). Pergamon. https://doi.org/10.1016/S02775395(99)00033-3

Rocheleau, D., \& Edmunds, D. (1997). Women, men and trees: Gender, power and property in forest and agrarian landscapes. World development, 25(8), 1351-1371. https://doi.org/10.1016/S0305-750X(97)00036-3

Saroha, E., Altarac, M., \& Sibley, L. M. (2008). Caste and maternal health care service use among rural Hindu women in Maitha, Uttar Pradesh, India. Journal of midwifery \& women's health, 53(5), e41-e47. https://doi.org/10.1016/j.jmwh.2008.05.002

Semaan, R. W., Lindsay, V., Williams, P., \& Ashill, N. (2019). The influence of gender roles in the drivers of luxury consumption for women: Insights from the gulf region. Journal of Retailing and Consumer Services, 51, 165175. https://doi.org/10.1016/j.jretconser.2019.06.006

Suacana, I. W. G. (2016). The gender equality and justice of Balinese women in traditional life. International Journal of Linguistics, Literature and Culture, 2(3), 45-55. Retrieved from https://sloap.org/journals/index.php/ijllc/article/view/117

Thompson, C. (1985). The power to pollute and the power to preserve: perceptions of female power in a Hindu village. Social Science \& Medicine, 21(6), 701-711. https://doi.org/10.1016/0277-9536(85)90210-2

Wibowo, D. E. (2012). Peran ganda perempuan dan kesetaraan gender. Muwazah: Jurnal Kajian Gender, 3(1).

Wildan, S. (2009). Kedudukan Dan Peran Perempuan Sebagai Istri Dalam Masyarakat Kraton Yogyakarta Hadiningrat (Studi Pertautan Hukum Adat Dan Hukum Islam). Skripsi. Universitas Islam Negeri Sunan Kalijaga, Yogyakarta. 